\title{
State Legal Responsibility if A Legal Malpractice and Malpractice Actions by Medical Personnel in the Implementation of the National Covid-19 Vaccination Program in Indonesia
}

\author{
Sainul $^{1} \quad$ Edi Ribut Harwanto ${ }^{2}$ \\ 1.Lecturer of Law Faculty of Syari'ah Islamic Institute of Religion Metro- Lampung \\ 2.Head of the Laboratory of Law Faculty, Muhamadiyah Metro University \\ Advocate-Lecturer in Economic Criminal and Intellectual Property Rights at the Law Faculty of Muhammadiyah \\ Metro University
}

\begin{abstract}
This study aims to find out the State Legal responsibility if a Legal Malpractice and Malpractice actions by Medical personnel in the implementation of the National Novid-19 vaccination programs in Indonesia. This research uses post-positivism paradigm. The researcher here, is neutral towards the object of research, even though the researcher holding this paradigm remains neutral towards the object of research, but he wants to examine what really happened from things that seemed certain. Consequently, ontologically the post-positivism paradigm conceptualizes law as a set of rules that apply in society whose validity will be influenced by legal, economic, political, cultural, and social factors. and others.The results of the author's research, in fact, in Indonesia, there are still many of our people who generally do not understand the science of mukasyafah and the science of understanding the regulations and procedures for the Covid-19 and khabar sadiq vaccination process. So that in the vaccination process, people do not prepare themselves regarding health information or accompanying diseases to vaccinate. Until in the end, death fell for the community, after vaccination, although it was not the main reason vaccination could cause death, it seemed that the incident became a truth value. Then, it appears, in indrak al hawass, ta'aqqul and qalb, which guarantees compensation for victims of vaccination who died due to being affected by the national vaccination immunization to their heirs who must the state gave them. Keywords: Criminal Sanctions, Vaccines, Covid-19, Medical Personnel, Vaccine Victims, AEFI, Constitutional Court and Supreme Court.

DOI: $10.7176 / \mathrm{JLPG} / 112-16$
\end{abstract}

Publication date:August $31^{\text {st }} 2021$

\section{INTRODUCTION}

The Covid-19 virus has become a trending topic in the international world, including in Indonesia. Regardless, the accusations of several related parties saying that the covid 19 virus from al-Hissiyat is a global business interest related to the world vaccine trade business, consider it a theme that becomes world public consumption as if it were khabar sadiq and let them settle international trade politics. and bear all the consequences that arise both in the world and in the hereafter if all these things are khabar kadhib. The community must follow the hobbesian pattern (all public order affairs can only be done through the law). We as human beings and good citizens, should be kind to state leaders and law enforcement officials in Indonesia, because in the teachings of Islam, It is recommended that every human being be kind to himself, to others and to the leader of the country. Because we don't know all the calamities of the Covid 19 virus, we can't be sure because "ma yatarajja' sidqulu wa lam yuqta' bi sidqihi', leave everything to Allah for all calamities that come to befall mankind in the world. However, we as human beings and citizens of Indonesia are obliged to obtain mujib lil-ilmu d-dhahari, in giving warnings and reprimands, if the state makes the wrong policy, of course with the guidance of Allah's law.

On the other hand, if the Covid-19 virus disaster is a punishment and is from qodarullah to human hypocrites who like to be immoral and unjust, then we as humans must not give up trying to stay istiqomah in maintaining our faith and Islam. That is to become us Muslim servants, believers, and muttaqin in the eyes of Allah. Trials come from Satan as well as tests from Allah, all of that is a destiny, we still treat it as a test from Allah. We have to act wisely even though we are affected by Allah's punishment, but believe me by trying and praying, always remembering Allah (remembrance of Allah), keeping the five daily prayers, always dhikr with thoyibah sentences, other sunnah prayers, then God willing we will saved from the punishment of Allah because we always keep our muru'ah. All events and from all calamities by Allah's permission. The incident of the Covid-19 virus disaster is also by Allah's permission, and Allah has willed all of this. All calamities on earth are the result of human activity. It can be done by humans or from the leaders of mankind who are cool with disobedience, lies, untrustworthiness, cunning, wickedness, disbelief, committing shirk, hypocrisy, and committing major sins and deliberately creating doubts (li-yuqi'u s-syankk wa r-rayb) in the midst of the people and their people. Allah says in the Qur'an; 


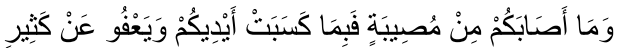

Meaning: "And whatever misfortune befalls you, it is due to the deeds of your own hands, and Allah forgives most (of your faults)." (Surah As-Shura Verse 30).

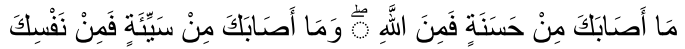

Meaning: "Whatever favors you get is from Allah, and whatever calamity befalls you, it is from yourself." (Surah An-Nisa verse 79).

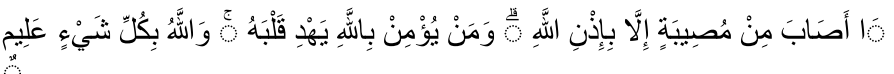

Meaning: "There is no misfortune that befalls a person except with Allah's permission; and whoever believes in Allah, He will surely guide his heart. And Allah is Knowing of all things." (Surah At-Taghabun Verse 11).

Referring to the word of God above, Something else bigger which deserves our attention in the middle Corona Virus disaster is to obey Allah's commands if they happen opinion on life in this world. ${ }^{1}$ Let's look at the empirical facts of the Covid-19 virus disaster or disaster that occurred in the world community, including Indonesia. Let's look at the graph of cases of the corona virus globally, which continues to increase. As of Monday (17/5/2021) morning, based on Worldometers data, the total number of cases of corona virus infection worldwide has reached 163,694,333 cases. Of that number, 3,392,634 people died, and 142,144,554 people were declared recovered. The United States is still the country with the highest number of cases to date. Covid-19 vaccination programs in various countries has begun, with each country registering a different percentage of vaccination coverage. Israel is the leading country in terms of vaccination, with the achievement of 58.9 percent of the population having received two injections of the vaccine. Followed by Chile 39.2 percent, Bahrain 36.8 percent, the United States 36.4 percent, then the UK 29 percent. The following is the vaccination achievement for each country, based on data compiled by Our World in Data up to May 15, 2021. ${ }^{2}$

From the data that has been collected as of July 1, 2021, through the news of the Merdeka.com mass media in Indonesia, the case is positive Covid-19 increased by 24,836 to 2,203,108 cases. ${ }^{3}$ The number of recovered patients increased by 9,874 to $1,890,287$ people. Patients died increased by 504 to 58,995 people, the death rate was quite high for the victims of the Covid-19 virus. A phenomenon, a major disaster nationally in Indonesia, including countries in the world, which were exposed to the Covid-19 virus, which claimed many deaths. A working meeting between the Indonesian House of Representatives Commission IX and the Chairperson (KIPI) discussed the vaccine victims in Indonesia revealed the facts of the vaccine victims, which were covered by journalists and published online on May 20, 2021 by the Detik Health media at 17.31 WIB. Chairman of the National Commission for Post-Immunization Adverse Events (KIPI) Prof. Dr. Hindra Irawan Satari in front of the House of Representatives Commission IX, revealed details of the case of death after vaccination. Good from the recipient Corona vaccine Sinovac, as well as the Astra Zeneca vaccine. Of the Sinovac vaccine recipients, there were 211 serious AEFIs, 27 of which died. Apart from death cases, all serious AEFI complaints such as shortness of breath to symptoms of nausea and weakness can be resolved. 27 people died from Sinovac. The details of the 27 victims of the vaccine are as follows, 10 people due to COVID-19 infection, 14 people due to heart and blood vessel disease, 1 person due to sudden kidney dysfunction, 2 people with diabetes mellitus, and uncontrolled hypertension. From the diagnosis, KIPI claims that it has complete data, examinations, treatments, X-rays, CT-Scans, labs, so that they can be diagnosed, so that everything is handled properly.

Meanwhile, in the case of the Corona Astra Zeneca vaccine, so far three cases of death have been recorded after vaccination. COVID-19 vaccine.The victims are East Jakarta youth aged 21 years, there is an elderly 60 years old who died after vaccination in DKI Jakarta. And, there is a victim of an online motorcycle taxi who died after the Corona vaccine, believed to be the cause of death due to pneumonia. He is 60 years old, an online motorcycle taxi comes to the vaccine service, is usually interviewed, but is not checked at the vaccination post health facility, is not checked, is immediately vaccinated. The next day the victim went to the clinic in DKI Jakarta, he was short of breath. He also said that he went to the clinic the day before he was vaccinated, he was already breathless, when he was examined at this clinic he had pneumonia. Meanwhile, the elderly was about to be intubated but refused. After being persuaded, the person concerned only agreed when the hospital facilities were full. (His condition) was getting worse and had to be referred, but there was no place, while his condition had to be intubated immediately but he refused. So that he died, this elderly person died of pneumonia, according to Prof. Hindra. One case died after the other Astra Zeneca vaccination came from Ambon. At the age of 45, he initially complained of a fever and a severe cold cough. Another one in Ambon, he was 45 years old, injected,

\footnotetext{
${ }^{1}$ Harwanto, E.R. (2021). Penolakan Rektor Perguruan Tinggi Negeri dan Perguruan Tinggi Swasta atas Demands Deliverance Uang Kuliah Tahunan Mahasiswa yang Terdampak Akibat Virus Covid-19. JUPIIS: Jurnal Pendidikan Ilmu-ilmu Sosial, 13(1): 138-148.

$2 \mathrm{https}$ ://www.kompas.com/tren/read/2021/05/17/093407265/update-corona-dunia-17-mei-33-juta-orang-meninggal-dunia-karena-covid-19.

${ }^{3} \mathrm{https}: / /$ www.merdeka.com/peristiwa/data-terkini-korban-virus-corona-di-indonesia-pada-juli-2021.html
} 
the next day he had a fever, coughed up a cold, then it was getting more aggravated, checked, his COVID-19 was positive, so he died three days later. He died from COVID-19, not from vaccines. As is known, in the case of East Jakarta youth which 21 years old, an autopsy of the body is being carried out to ensure that the person concerned does not die from the COVID-19 vaccine. Such is the empirical reality that occurs in Indonesia, the victims of the Covid-19 vaccine. Furthermore, despite all the arguments from KIPI, the author will see from the optics of the law on the criminal answer of vaccine victims who have died in the world, due to the alleged negligence of medical personnel when doing vaccines without going through medical record examinations, or interviews with the public who will conduct vaccines and conduct health checks on the public.

The problem of the Covid-19 virus phenomenon, the author sees from not one paradigm point of view, but combines two paradigms of positivism with the paradigm of dogma and theology values as the main source in unraveling a problem. Thus, in the process of decomposing a problem, it is both outward and inward, outwardly representing state law with its positive law, inwardly representing God's law as a guide and determinant which contains regulations for living in the world by prioritizing prophetic values as a legal basis in managing life in the world. Do not let, in enforcing the law of order, behave in health protocols due to the Covid-19 Virus, the state seems to be a "domenieering being" Who has the ambition and tendency to control and conquer others and force them to submit and obey him, (Ibn Khaldun)., ${ }^{1}$ The state must be fair and pay attention to the aspirations of the people in taking action and making and taking aqliyah laws and regulations that are widely opposed by the people because the fallacies apply the values of justice and freedom of movement and freedom of economic space. In the context of the Covid-19 virus problem. The author divides three main problems, one main problem is to break down the belief in prophetic values which refers to the doctrine in this case is the teachings of the Godhead of the Qur'an and Al-Hadith and two main problems discuss special cases and efforts to take action against violators and efforts to prevent victims or every citizen of the implementation of human rights and constitutional rights in the context of making the law and the legislation in force in Indonesia (the law of positivism). The community must first find out the truth as well as the track record of related cooperatives as a precaution. People don't be easily tempted. The people behind this scam are targeting the consumptive society in an easy and fast way but without control. ${ }^{2}$ The three main discussions are based on al-hasan wa -iqubh 'aqliyayn; (1) Is the calamity or disaster of the Covid-19 Virus that occurred in Indonesia is a disaster that comes by the will of Allah and by Allah's permission?, (2) How is the state's legal protection for victims who died as a result of the national vaccination program in Indonesia due to the negligence of medical personnel who did not implement operational standards in implementing the vaccination program?, (3) What law is the basis for legal protection for every Indonesian citizen, if the state makes coercive measures against the national vaccination program in Indonesia.

These three main problems, the authors will discuss in detail by citing authentic legal sources and can be used as a legal basis for every Indonesian citizen in making an argument for the impression that there is an element of coercion of will on the implementation of a systematic national vaccination program involving all elements, officials executive, legislature and judiciary, TNI (Indonesian Army), Polri (Indonesian Police), Prosecutor Judge, Pol PP (Municipal Police), and supported by other religious organizations. An example as an indicator of a national vaccination program that looks like there is an element of systematic coercion is, every trip outside the city, people must show a vaccination certificate, if they do not have a Covid-19 vaccine certificate, they cannot travel outside the region. The people seemed to be forced to insert blinding regulations and were led so that all people were obliged to follow the national vaccination, and to follow all government regulations in order to maintain the safety and health of the people. Though not all people can be vaccinated for reasons of health and history of illness. there needs to be an increase and awareness that everyone in facing this era must have a new awareness, in this digital era they must be more aware of protecting data and always protecting it. ${ }^{3}$ The vaccination victims who died had a history of illness, which was not detected by unscrupulous medical personnel who did not conduct interviews and health checks to the people who would be vaccinated. In the event that a victim of a criminal act asks for a merger of a compensation case, the court is obliged to consider the authority to adjudicate the claim regarding the truth of the basis of the claim and the penalty for the payment of the costs incurred by the victim. ${ }^{4}$

Therefore, The author will solve three problems one to three in accordance with the optics of the paradigm of dogma law and theology and positive law of the state with the aim of enlightening the protection of the constitutional rights of every citizen and educating the public scientifically and the correct way of law in order to

\footnotetext{
${ }^{1}$ Adian Husaini, Filsafat Ilmu, Geman Insan, Jakarta, 2013, Hhl :128

${ }^{2}$ Harwanto, ER, The Criminal Action of Money Launching and Funding of Members in the Baitul Maal Wa Tanwil Cooperative by the Management and Members of Cooperative in Indonesia, JL Pol'y \& Globalization, 2021, 106, 42

${ }^{3}$ Andi Aina Ilmih \& Edi Ribut Harwanto, Law Enforcement and Prevention of Banking Criminal Actions in Indonesia, Turkish Journal of Computer and Mathematics Education (TURCOMAT), 2021, 12(3), 5733-5744.

${ }^{4}$ Harwanto, ER, Juridical Anomaly; Criminal Provisions on Copyright Law No. 28 of 2014 (Juridical Anomals related to Determination of Qualification of Delices, Determination of Criminal Sanctions of Criminal, Criminals of Pregnancy, Complaints and Revocation of Credit Co, Journal of Talent Development and Excellence, 2020, 12(1), 1609-1613.
} 
guard against the threat of arbitrary human rights actions carried out by the state or law enforcement tools in carrying out other laws that implement other laws which over the limit.

This study aims to find out the State Legal responsibility if a Legal Malpractice and Malpractice actions by Medical personnel in the implementation of the National Novid-19 vaccination programs in Indonesia

\section{RESEARCH METHOD}

This research uses post-positivism paradigm. The researcher here, is neutral towards the object of research, even though the researcher holding this paradigm remains neutral towards the object of research, but he wants to examine what really happened from things that seemed certain. Consequently, ontologically the post-positivism paradigm conceptualizes law as a set of rules that apply in society whose validity will be influenced by legal, economic, political, cultural, and social factors. and others.

\section{DISCUSSION}

A. Is the calamity or disaster of the Covid-19 Virus that occurred in Indonesia is a disaster that comes by the will of Allah and by Allah's permission?

In the first discussion, the author looks at the problem of the Covid-19 Virus, by departing from the assumption of the basic philosophical question, "Is the calamity or disaster of the Covid-19 Virus in Indonesia a disaster that comes with the will and permission of Allah". Plato and Aristotle, philosophers from ancient Greece, who lived in (427-347) believed that the world was divided in two, namely the real world and the ideal or idiomatic world. Real nature is as it exists on earth. The realm of ideos is a world that contains eternal truths that must be a guide for living in the real world. The world of ideos comes from Divinity (supreme power) where the divine power is eternal, eternal which is perfect and very good. ${ }^{1}$ In the context of the number one question in the discussion about the existence of the phenomenon of the Covid-19 Virus, the author argues that this virus is a disaster that was intentionally sent and with the permission of Allah which is from the relationship between ideos and the real world.

This disaster, which originates from the ideological world, has a special purpose to remind all human beings who have acted unjustly, are immoral, despots, lies, hypocrites, envy, polytheists, untrustworthy, disbelievers, and with all kinds of grave sins committed by humans who are no longer afraid of God. Regardless of this calamity being carried out by demons from the human race or demons from the jinn, which afflicts mankind in the world, but all of these disasters are at will by the will and permission of Allah, in the science of Islamic fiqh, "taqhayyur al-ahkam bi taghayyur al-azminah wa al-amkinah". All events of time and place and all changes in the contents of the world are all by the will of Allah. Let all that be a secret of Allah, whether all this calamity is a punishment or a trial for humans.

The verse that states, even all calamities are with the permission and will of Allah, which originate from human behavior and the leaders of the country whose manners and morals have been damaged and exceeded the limit.

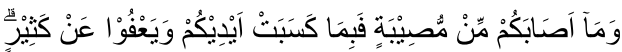

Meaning "And whatever calamity befalls you is caused by the deeds of your own hands, and All ah forgives most of your iniquities." (Surah As-Shura Verse 30).

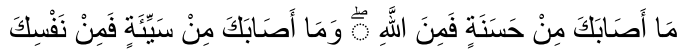

Meaning: "Whatever favors you get is from Allah, and whatever calamity befalls you, it is from yourself." (Surah An-Nisa verse 79).

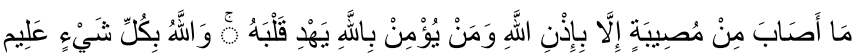

Meaning: "There is no misfortune that befalls a person except with Allah's permission; and whoever believes in Allah He will surely guide his heart. And Allah is Knowing of all things." (Surah At-Taghabun Verse 11).

Listening to the three holy verses of the Qur'an, it is clear that all kinds of calamities befall humans because they are caused by human actions, and Allah will forgive most of human mistakes. The essence of the second verse, Surah An-Nisa Verse 79, is that all the blessings of human sustenance are from Allah, and all kinds of disasters that befall humans are the result of human error. The essence of the third verse, surah At-Taghabun verse , all calamities that befall all humans are all by Allah's permission, which only people who believe in Allah will be given guidance and protection for their hearts. From the essence of the three holy verses of the Qur'an, Allah has informed all mankind on this earth, that all disaster and calamities, including the Covid-19 Virus, this is also part of one of the calamities or disasters that are all by Allah's will.

The death of a human being, in the interpreter of this world is also by the will of God. So that Allah sends

\footnotetext{
${ }^{1}$ FX, Adji Samekto, Hukum Dalam Lintasan Sejarah, Indepth Publishing, 2013-hlm 13-14
} 
punishment to humans, so that even good people are affected, even though it is aimed at humans who disobey Allah's law. Let all of that be a secret of Allah, for all this calamity, let's try to ask for Allah's protection and carry out all his commands as stated in the holy book of Al-Qur'an and Al-Hadith. This has been done by the leader of this country, the legislator, who has relied on religious knowledge as the most important part in regulating mankind on this earth.

The religious approach is a mandate and at the same time a demand for the National Building of BANGNAS and the National Law Building and the National Legal System that has been intended to be a National Law System that has Pancasila. This means that every law or regulation made by the state must pay attention to religious values which factually must be implemented, not only theories in the text book of laws and regulations. The national signs above clearly demand a «religious approach». Even with the often called «Pancasila justice» and the provisions in the Law on Judicial Power, that "Judges are obliged to explore, follow, and understand the legal values and sense of justice that live in society", it can be said that the SISKUMNAS signs emphasize the need for a «cultural-religious approach».

From the signs above, it is clear that there should be no «secularism» in the National Legal System, including law making/formation, law enforcement, and national legal education/science. Religious values must be considered, religious space in the rules must be given a place, it should not become a barrier in the implementation of inter-religious worship in Indonesia. This means that positive law in Indonesia, which relates to the rules regarding the Covid-19 Virus, national vaccinations, restrictions on people's movement space, whether social, economic, educational, and other spaces, must be synchronized with God's law. This means that in making laws and providing public services, the state must pay attention to the voice of the people and the people, do not make rules but seem to oppress the people and violate religious norms, ethics, morality and cause noise among the people.

In this context, the regulation of laws and regulations, related to the application of sanctions during the Covid-19 Virus, the Imposition of Emergency Community Activity Restrictions for the Java and Bali regions and finally also in various parts of the regencies and cities in Indonesia, it is necessary to pay attention to the economic impacts, social, political, legal, and community psychology and aspects of religious law. Religion becomes the most important point, because so far the worship of religious people has been hindered all this time. If the state pays attention to the laws of ideology and natural law and can interpret the thoughts from Allah, then it will minimize the punishment of Allah.

If, the leader of this country, believes in the law of God, which has been poured in the 1945 Constitution and special statutory tools under the Dara Act 1945, then by the pleasure of Allah, it is also a magical metaphysical effort that is also carried out in addition to positive law enforcement efforts made by the state. Therefore, what is more important is that a national vaccination program that seems like the state requires its people to participate in national vaccinations with various approaches and inserts inserts into national administrative regulations is okay, but never force people who are not willing to be vaccinated in a health and illness, young or old.

\section{B. How is the state's legal protection for victims who died as a result of the impact of the national vaccination program in Indonesia due to the negligence of medical personnel who did not implement operational standards in implementing the vaccination program?}

International Law of Human Rights (HAM) is the most basic and natural right (negative right), because it is natural, in fact it does not require juridical legitimacy to enforce it in a national or international legal system. ${ }^{1}$ These human rights are universal. Where these human rights apply to all people of various races, tribe, ethnicities, religions and positions. The United Nations(PBB) has held international conventions and treaties in various countries to ensure that these countries protect the human rights of each of its people. Although the United Nations has issued a statement on human rights and has drawn up a series of ruleslaw In order to protect individuals throughout the country, in fact there are still a number of human rights violations being found. According to the Law of the Republic of Indonesia No. 26 of 2000 concerning the Human Rights Court, has explained the definition of human rights violations. Human rights violation is every act of a person or group of people including state apparatus, whether intentional or negligent, whichlawreduce, hinder, limit and or revoke the human rights of a person or group of people guaranteed by this law, and are not obtained or are feared that they will not obtain a fair and correct legal settlement, based on the applicable legal mechanism. The 1945 Constitution as the highest source of law in Indonesia, after Pancasila, the 1945 Constitution becomes the reference for all laws and regulations under it.

The concept of human rights has become more clearly regulated in the sense that it has its own place, namely in Chapter XA on Human Rights, plus several articles outside the chapter which still contain human

\footnotetext{
${ }^{1}$ Pusat Studi Hukum dan Hak Asasi Manusia IAIN Sultan Maulana Hasanudin Banten, Buku Ajar, Hak Asasi Manusia dalam Berbagai
} Bidang Ilmu,hlm. 1 
rights material. This limited mention has implications that other rights outside this Article have the meaning of being derogable rights. In the context of how the state's legal protection for the victims who died as a result of the national vaccination program in Indonesia as a result of the alleged impact and the result of the negligence of medical personnel who did not implement operational standards in implementing the national vaccination program in Indonesia. The victims of the national vaccination, which are suspected to have died as a result of the national vaccination program, are still being researched and some are being subjected to vorensic tests by the police on the bodies of victims of the national vaccination.

The highest national law in Indonesia in order to ensure that every citizen has been regulated as stated in the text in the Article 28D paragraph and of the 1945 Constitution , "Everyone has the right to recognition, guarantee, protection, and legal certainty that is fair and equal treatment before the law". In the 1945 Constitution, explicitly in the text everyone means that it applies to all Indonesian citizens, to gain recognition as citizens, to obtain protection for their fate in connection with the national vaccination program for the Covid-19 Virus. And get legal certainty, that the state guarantees that the use of the Covid-19 national vaccination program ensures a sense of security and does not threaten the safety of the life of every citizen, fairly and treats every citizen equally. Furthermore, in the 1945 Constitution Article $28 \mathrm{G}$ paragraph, Which contain that, every citizen has the right to personal and family protection, to honor, to dignity.

As well as the right to a sense of security and protection from the threat of fear to do or not do something that is a human right. In this case, if the state makes a semi-coercive effort through an insertion strategy in government administration policies, for example travel between cities is required to have a vaccine certificate, it shows an indicator of an integrated and collective coercive effort carried out with a pattern of inserting certain rules that violate the law and the constitution. This is related to the implementation of the national vaccination program, which raises many pros and cons in the community, regarding the direct impact after a person is vaccinated nationally. Appeared in the area in some areas, on social media, stories and incidents of community members after vaccination, some were inflamed, swollen, paralyzed, short of breath, stomach pain and some died afterward.

In the minds of the people, high anxiety creates distrust of state policies that cannot guarantee a sense of security from the threat of vaccination impact nationally, because many victims fall, but also many people after vaccination are safe and do not experience any problems. The number of people who are healthy after the vaccine is more than those who are affected by the vaccine, however, the number of victims of the national vaccination who died is still small, although officially the country has not released directly whether there is an impact of national vaccination on human health, but the public has seen the factual conditions directly become victims and through mass media news and online news. Chairman of the National Commission for PostImmunization Adverse Events Prof. Hindra Irawan Satari in front of the House of Representatives Commission IX, revealed details of the case of death after vaccination.

Both from corona Sinovac vaccine recipients, and Astra Zeneca vaccine. Of the Sinovac vaccine recipients, there are 211 serious AEFI, 27 of which are left in the world. The details of the 27 victims of the vaccine are as follows, 10 people due to COVID-19 infection, 14 people due to heart and blood vessel disease, 1 person due to sudden kidney dysfunction, 2 people with diabetes mellitus, and uncontrolled hypertension. Meanwhile, in the case of the Corona Astra Zeneca vaccine, so far there have been three cases of death after vaccination.

The three are believed by Prof Hindra to be unrelated too COVID-19 vaccine. The victims are East Jakarta youth, there is an elderly 60 years old who died after vaccination in DKI Jakarta. And, there is a victim of an online motorcycle taxi who died after the Corona vaccine, believed to be the cause of death due to pneumonia. $\mathrm{He}$ is 60 years old, an online motorcycle taxi comes to the vaccine service, is usually interviewed, but is not checked at the vaccination post health facility, is not checked, is immediately vaccinated.

After being persuaded, the person concerned only agreed when the hospital facilities were full. As is known, in the case of a 21-year-old East Jakarta youth, an autopsy is being carried out to ensure that the person concerned did not die because of the COVID-19 vaccine. This fact shows that the vaccination program launched by the government has not been able to convince the Indonesian people so that many part of the community refuse to take vaccinations because they have fear and doubt about being vaccinated. Although, according to information from KIPI, the victims who died were not caused directly from the vaccine, but people still feel doubtful, because they were healthy before the vaccine, after the vaccine died, the fact of death is the point of public attention.

In this case, the community or every citizen has the right to defend their right to life, because they are afraid and do not believe in the implementation of the national vaccination program. Participating in and not participating in the vaccination program is the constitutional right of every citizen. Because of feelings of fear and lack of confidence in the implementation of the vaccine, the state must not make coercive measures for every citizen, because the right to life and life is guaranteed by the 1945 Constitution. If there is a violation of this, Legal action can be taken to the General Court and Human Rights Court as well as to the District Court, on suspicion of unlawful acts carried out by state officials or medical personnel who commit malpractice actions 
when taking medical actions.

So if this happens and continues, the state has the potential to commit violations of human rights and the 1945 Constitution which can be sued at any time by the people.

\section{What law is the basis for legal protection for every Indonesian citizen, if the state makes coercive measures against the national vaccination program in Indonesia.}

Legal protection for every citizen is guaranteed by the constitution. Therefore, the state should not limit the movement space of every citizen, or limit public services which are the legal rights of every citizen, just because they do not want to participate in the national vaccination program. Of course, citizens who are not willing to vaccinate, have clear legal arguments and reasons, to protect themselves and their families seeing the reality of victims of vaccination falling everywhere. Even though the state has never officially stated that the impact of vaccines can result in death or other illnesses, people are still traumatized by the reality of mass media reporting, so that doubts arise in the minds of the wider community. In order to provide legal protection, The constitutional rights of every Indonesian citizen are clearly stated in the 1945 Constitution can be read in Article 27 on equality in law, Article 28 on freedom of association and assembly, Article 28A on the right to life, Article 28B on the right to family, Article $28 \mathrm{C}$ on the right to develop themselves, Article $28 \mathrm{D}$ on the right to fair legal treatment and legal certainty, Article $28 \mathrm{E}$ on the right to religion, Article $28 \mathrm{~F}$ on the right to communicate, and Article $28 \mathrm{G}$ on the right to security.

Therefore, the state through the workers of civilian medical personnel, military medical personnel and police medical personnel who help the government in the success of the Covid-19 national vaccination program must be careful in implementing operational standards in carrying out the national vaccination program. Because, it really determines the success of the Covid-19 national vaccination program. To see in detail how the mechanism is and the flow of COVID-19 vaccination services at clini, other health service facilities and vaccination service posts, has been regulated in Decree of the Director General of Disease Prevention and Control Number Kemenkes, number: HK.02.02/4/1/2021 regarding the Technical Guidelines for the Implementation of Vaccination in the Context of Combating the COVID-19 Pandemic. The regulation is for the target recipients of the COVID-19 vaccine who have re-registered and arrived on time according to the schedule at the specified location, will register and register at Table 1 . Then the officer will screen at Table 2 , followed by vaccination at the table 3 and recording of vaccination results at table 4 . In the phase, table 2 of the implementation of this screening, malpractice is prone to occur by unscrupulous medical personnel who carry out the spearhead of the success of the national vaccination program. Thus, people who have a history of illness, as a result of participating in the vaccine program, actually arise new problems, because their bodies are not healthy. In this phase, table 2 is, Criminal Liability Against Doctors Who Perform Malpractice Actions. Medical personnel, health workers, nurses, etc. or doctors are obliged to provide the best possible medical services for patients, this medical service can be in the form of providing medical action according to the medical service standards required for the recovery of the patient, but sometimes the results achieved by the doctor are not as expected because Lack of skills and knowledge of doctors which results in malpractice (medical errors made by doctors) against patients which causes disability or death.

In civil law the victim's family if someone dies can sue to the District Court with the provisions of Article 1365 BW, "Any act that violates the law and brings harm to others, obliges the person who caused the loss by his or her fault to take the cost." If, will make a civil lawsuit, can directly file a lawsuit directly to the District Court, where the medical personnel live. If, file a criminal report to the police then it must make an official report to the doctor who handles vaccinations, who allegedly neglect screening so that there is malpractice, so as not to detect in a simple medical record to patients who will do the vaccine. In Law Number 36 of 2009 concerning Health contains 12 articles that regulate criminal provisions, namely Articles 190 to 201. Material crimes are regulated in Article 190 paragraph and Article 191 and the remaining articles regulate formal criminal acts.

Health is a human right and is a concern for everyone, because of the development of malpractice emerging as a new concept of science which is inversely proportional to the knowledge or understanding of health that is developing in the community. Based on the existing problems, in this Journal a formulation of the problem can be drawn concerning how the accountability of medical personnel in the criminal act of malpractice in handling Covid-19 vaccination to the public is seen from the perspective of Law no. 36 of 2009 concerning Health and Law no. 36 of 2014 concerning Health Workers.

In Article 190 paragraph of Law no. 36 of 2009 concerning Health, health workers are sentenced to 10 years in prison. While Article 84 paragraph of Law no. 36 of 2014 concerning Health Workers, sentenced to a maximum of 5 years in prison.

For medical personnel, doctors, nurses or other health workers, who intentionally commit malpractice negligence, the criminal sanctions are clear. Therefore, the heirs whose family members may become victims because the vaccine was carried out without screening first to detect the patient's congenital disease, so that operational standards are not carried out and result in the loss of the patient's life or the community, legal action 
can be taken both criminally and civilly by the heirs or his family.

Constitutional Court is obliged to give a decision on the opinion of the DPR that the President and/or the Vice President are suspected of having committed an impeachment. Meanwhile, if there are regulations made by the president, in the form of presidential regulations, ministerial regulations, governor regulations, mayoral regulations and regent regulations equivalent to regional regulations related to regulations regarding Covid-19 which are contrary to the law and are detrimental to the community, then the community independently Directly affected persons who suffer legal losses due to the enactment of special laws that are contrary to the 1945 Constitution can file a judicial review lawsuit to the Supreme Court of the Republic of Indonesia, either independently or in groups in the form of a class action lawsuit. The function is to provide legal advice to the President in granting and denying clemency and rehabilitation as well as providing legal considerations to other State High Institutions. Therefore, the public or community groups who feel disadvantaged by the enactment of laws relating to the field implementation of Covid-19, have directly or indirectly harmed the community, can use their constitutional rights to file a material test lawsuit. If, which will be sued in the form of laws and regulations then the meteril test lawsuit can be requested to the Constitutional Court of the Republic of Indonesia.

As for medical regulations, which relate to public health, the rules are clear. Not just anyone can be vaccinated, the results obtained may not be optimal. There are several conditions related to the condition of the body that must be prepared before vaccination, as quoted from CNN Indonesia news Tim, CNN Indonesia Wednesday, 13/01/2021 10:12 WIB sourced from the State Palace Medical Internal Medicine Expert Team, Prof. Abdul Muthalib.

1. Healthy body Vaccination is the process of administering a biological product to stimulate an immune response. Because it is a biological product and the expected effect is an immune response, the main requirement for people receiving the vaccine is that the body is in good health.

2. Without fever, the body condition of the fever should not be vaccinated at all, the body temperature must be stable when administering the vaccine.

3. Age appropriate Vaccines are usually intended for people of a certain age. In the case of Sinovac's Covid-19 vaccine, the vaccine is intended for people aged 18-59 years. Children and the elderly outside the age group should not get the vaccine.

4. Controlled comorbidities. Those who have co-morbidities including diabetes and uncontrolled hypertension are not advised to get vaccinated. Comorbid or congenital disease must be under controlled conditions and get approval from the treating doctor, then you can get the vaccine.

5. Do not have an autoimmune disease specifically for Covid-19, vaccines are not recommended to be given to those who have autoimmune diseases, as stated in the recommendations from the Indonesian Allergy Immunology Association (PP Peralmuni). The reason is, until now there has been no research related to the effectiveness of vaccines against people with autoimmune diseases. Autoimmune patients are not recommended for Covid-19 vaccination. Until clearer research results have been published. ${ }^{1}$

\section{CONCLUSION}

1. In the discussion above, the author concludes, that in order to provide an understanding of the heart to the people and tsiqah fi dinihi, as well as in understanding the meaning of disaster or disaster. This disaster is the Covid-19 Virus in Indonesia. Khabar sadiq is a trusted source, there will be calamities that come all by the will and permission of Allah and are directly connected to His command. Because the Qur'an has explicitly stated, "And whatever misfortune befalls you, it is due to the deeds of your own hands, and Allah forgives most (of your faults)." (Surah As-Shura Verse 30). This awareness is to open horizons for mankind so that the establishment of ma'rifatullah can be used as a guide in assessing a situation that is always connected with the power of ideos. The meanings and premonitions are seen in this Covid-19 virus disaster and disaster so that it can be read and interpreted as a test for pious people and punishment for sinners, unjust leaders, humans commit a lot of disobedience, lies, envy, commits major sins in the world.

2. The state's legal protection for victims who died as a result of the national vaccination program in Indonesia due to the negligence of medical personnel who did not implement operational standards in implementing the vaccination program must be legally processed. Legal facts found elements of violations of unlawful acts, in the screening process phase, there were elements of negligence, so that patients who wanted to be vaccinated were not first examined by medical personnel so that the patient's history of accompanying illness was not detected, resulting in the death of the patient due to indications of malpractice. then law enforcement must be enforced. Law No. 36 of 2009 concerning Health and Law no. 36 of 2014 concerning Health Workers. As for the conclusion of this journal, namely in Article 190 paragraph (2) of Law no. 36 of 2009 concerning Health, health workers are sentenced to 10 (ten) years in prison. While Article 84

\footnotetext{
${ }^{1}$ https://www.cnnindonesia.com/gaya-hidup/20210111141633-255-592171/syarat-vaksinasi-yang-perlu-diketahui
} 
paragraph (2) of Law no. 36 of 2014 concerning Health Workers, shall be sentenced to a maximum imprisonment of 5 (five) years. Efforts for a civil lawsuit to the District Court can also be made by filing a lawsuit against the law (PMH) for heirs who feel that they have been harmed due to alleged malpractice actions by medical personnel.

3. In order to provide legal protection to every color of the state, the 1945 Constitution, the Human Rights Law, is regulated in what is the basis for legal protection for every Indonesian citizen, if the state makes a forced effort against the national vaccination program in Indonesia. The 1945 Constitution can be read in Article 27 concerning equality in law, Article 28 concerning freedom of association and assembly, Article $28 \mathrm{~A}$ concerning the right to life, Article $28 \mathrm{~B}$ concerning the right to have a family, Article $28 \mathrm{C}$ concerning the right to self-development, Article 28D concerning the right to fair legal treatment and certainty. law, Article $28 \mathrm{E}$ on the right to religion, Article $28 \mathrm{~F}$ on the right to communicate, and Article $28 \mathrm{G}$ on the right of security. Efforts can be made to conduct a legal meter test to the Constitutional Court of the Republic of Indonesia if there are laws and regulations that are contrary to the 1945 Constitution and a material test to the Supreme Court of the Republic of Indonesia, if there are regulations under the Law on Covid-19 that are contrary to the law, such as the Presidential Regulation, ministerial regulations, gubernatorial regulations, regional regulations etc. rules under other relevant laws.

\section{REFFERENCES}

\section{Book}

Adian Husaini, Filsafat Ilmu, Geman Insan, Jakarta, 2013, Hhl :128

\section{Journal}

Barda Nawawi Arief, Reformasi Sistem Peradilan (Sistem Penegakan Hukum) Di Indonesia, dalam Bunga Rampai Potret Penegakan Hukum Di Indonesia, Komisi Yudisial Rep. Indonesia, 2009.

FX, Adji Samekto, Hukum Dalam Lintasan Sejarah, Indepth Publishing, 2013-hlm 13-14

Harwanto, E. R. (2020). Juridical Anomaly; Criminal Provisions on Copyright Law No. 28 of 2014 (Juridical Anomals related to Determination of Qualification of Delices, Determination of Criminal Sanctions of Criminal, Criminals of Pregnancy, Complaints and Revocation of Credit Co. Journal of Talent Development and Excellence, 12(1), 1609-1613.

Harwanto, E. R. (2021). The Criminal Action of Money Launching and Funding of Members in the Baitul Maal Wa Tanwil Cooperative by the Management and Members of Cooperative in Indonesia. JL Pol'y \& Globalization, 106, 42.

Harwanto, E. R. Penolakan Rektor PTN dan PTS atas Demands Deliverance UKT Mahasiswa yang terdampak akibat Virus Covid-19. JUPIIS: JURNAL PENDIDIKAN ILMU-ILMU SOSIAL, 13(1), 138-148.

Ilmih, A. A. (2021). Law Enforcement and Prevention of Banking Criminal Actions in Indonesia. Turkish Journal of Computer and Mathematics Education (TURCOMAT), 12(3), 5733-5744.

\section{Regulations}

Undang-Undang No. 36 Tahun 2009 Tentang Kesehatan

Undang-Undang No. 36 Tahun 2014 Tentang Tenaga Kesehatan

Pasal 190 ayat (2) UU No. 36 Tahun 2009 Tentang Kesehatan

Pasal 84 ayat (2) UU No. 36 tahun 2014 Tentang Tenaga Kesehatan,

\section{Internet}

Jawahir G. Rizal, https://www.kompas.com/tren/read/2021/05/17/093407265/update-corona-dunia-17-mei-33juta-orang-meninggal-dunia-karena-covid-19.

Wisnoe Moerti, https://www.merdeka.com/peristiwa/data-terkini-korban-virus-corona-di-indonesia-pada-juli$\underline{2021 . h t m l}$

Tim CNN Indonesia, https:/www.cnnindonesia.com/gaya-hidup/20210111141633-255-592171/syaratvaksinasi-yang- 